\title{
Tritium influence on morphology, reactive oxygen species production and catalase gene expression in Pseudendoclonium basilense and Stigeoclonium nanum (Chlorophyta)
}

\author{
Petr HašLer, Vladan OndŘeJ, Michaela ŠvéCARovÁ, Michaela SedláŘové, Barbora \\ VAIDOVÁ \& Aloisie PoulíčKová
}

\author{
Department of Botany, Faculty of Science, Palacký University, Šlechtitelì 27, CZ-783 71 Olomouc, Czech \\ Republic; *Corresponding authore-mail: petr.hasler@upol.cz
}

\begin{abstract}
The response of two strains of Pseudendoclonium basilense VISCHER and Stigeoclonium nanum (DILLWYN) KÜTZING to ionizing radiation was studied under laboratory conditions. Both strains were isolated as epiphytic from stagnant water bodies under ambient levels of ionizing radiation and cultivated under laboratory conditions on a gradient of tritiated water diluted in liquid Bold's basal medium. Exposure to low doses of ionizing radiation stimulated changes in cell dimensions and morphology of in both strains and catalase gene expression in Pseudendoclonium basilense. Moreover, the addition of tritiated water stimulated production of reactive oxygen species in Pseudendoclonium basilense which concentration decreased after increased gene expression of catalase.
\end{abstract}

Key words: oxidative stress, ionizing radiation, adaptation, tolerance, catalase, nuclear power plant, green algae

Abbreviations: (ROS) reactive oxygen species, (RONS) reactive oxygen and nitrogen species

\section{INTRODUCTION}

Ionizing radiation influences metabolism, ultrastructure, and the biology of organisms both directly and indirectly (KovÁcs \& Keresztes 2002). The energy of ionizing radiation determines the extent of its impact on biological systems, leading to minor variations, severe damage or even to a cell death. Tritium, a soft $\beta^{-}$emitter, is considered as one of the safest radioisotopes with low linear energy transfer causing a low degree of damage (BLAYLOCK et al. 1986). Almost 99\% of tritium produced by the action of cosmic rays in the upper layers of atmosphere is transformed into tritiated water which is spread in the surface water layer (CALMON \& Garnier-Laplace 2010). Anthropogenic tritium is produced mainly in the form of tritiated water. Large amounts of tritium may be released into the environment from nuclear power plants (FIÉVET et al. 2013). In the Czech Republic, the Temelín nuclear power plant discharged nearly $30 \mathrm{Tbq}$ of tritium in 2005 (HANSLíK et al. 2009).

KirCHMANN et al. (1979) proved that tritium concentration is equals in the environment, e.g. water, culture medium, and algal biomass. Similarly, the ratio of tritium fixed in algal organic matter (e.g. incorporated in membranes, organelles, structural macromolecules) and within the cytosol is equal. This is because algae persist in a stable state of uptake and release with respect to their short life and simple cell or thallus organization (HARRISON 1971). Algae and higher plants can assimilate then incorporate tritium into macromolecules such as proteins and DNA through photosynthesis, especially water photolysis. The intensity of algal assimilation can be expressed as a function of incorporated tritium or specific activity inside cells. For example, Acetabularia sp. shows rapid growth after tritium incorporation followed by long and slow growth rate (BоNOTTO et al. 1982).

Tritium behavior in the environment and its incorporation into algal biomass has been studied both under laboratory conditions and in the field over last 50 years (Kirchmann et al. 1979; Belot 1986; McCubbin et al. 2001; Kim et al. 2012; Fievet et al. 2013; Baglan et al. 2013; Jean-Baptiste \& Fourre 2013). One can 
perceive incorporated tritium, and its ionizing radiation respectively, as a form of abiotic stress. Tritium incorporation into algal DNA can cause chromosomal aberration, breakage, and mutation and subsequently can influence the physiological state of cells, particularly cell stress, biochemical pathways and overall metabolism. Abiotic stress (e.g. heat, salinity, heavy metals, desiccation or radioactive irradiation) can induce the formation of reactive oxygen species (e.g. $\mathrm{O}_{2}^{-}, \cdot \mathrm{OH}, \mathrm{H}_{2} \mathrm{O}_{2}$ ) which can cleave biomolecules and also transduce signals. Cell stress responses including variation in metabolism, growth, and development are based on ROS interplay with plant hormones. Studies on higher plants confirmed stress-induced morphological responses to increased concentration of auxins in plant cells (e.g. PotTers et al. 2007). Reactive oxygen species could enhance auxin-responsiveness in cell cycle reactivation, re-orientation of growth and polar cell expansion (PASTERnAK et al. 2005; MANGANO et al. 2016). However, the effect of ionizing radiation on both algal cell morphology and ROS production during stress have not been previously studied.

Regulation of oxidative stress tolerance in plant cells, and likely in green algae as well, represents a complex regulatory system among plant hormones and enzymes. This strictly balanced system maintains cell homeostasis and protects against cell damage or death. Catalase $\left(\mathrm{H}_{2} \mathrm{O}_{2}: \mathrm{H}_{2} \mathrm{O}_{2}\right.$ oxidoreductase; EC 1.11.1.6) is a tetrameric heme-containing enzyme that convert hydrogen peroxide $\left(\mathrm{H}_{2} \mathrm{O}_{2}\right)$ to oxygen and water thus protecting the cell from the damaging effects of hydrogen peroxide accumulation. These enzymes can catalyze direct degradation of hydrogen peroxide or its depletion by different substrates (e.g., methanol, ethanol, formaldehyde, nitrite) oxidation (DAT et al. 2000; McCLUNG 1997).

The aim of this study is to investigate morphological changes, ROS production, and catalase gene expression in two green algae, Pseudendoclonium basiliense and Stigeoclonium nanun, under a gradient of soft $\beta^{-}$irradiation from tritiated water. Both P. basilense and $S$. nanum are periphytic species frequently inhabiting stones or submerged macrophytes in stagnant and flowing waters which can be polluted by human nuclear waste.

\section{Material And Methods}

Experimental design. Two strains of Pseudendoclonium basiliense (strain Vaidová 2014, isolated as epiphytic, pond near Dolní Benešov, Czech Republic) and Stigeoclonium nanum (strain Vaidová 2014/1, isolated as epiphytic, pond near Velká Bystřice, Czech Republic) were maintained for three weeks under laboratory conditions as follows: continuous irradiation of $20 \mathrm{mmol} \cdot \mathrm{m}^{-2} \cdot \mathrm{s}^{-1}$, temperature of $15{ }^{\circ} \mathrm{C}$, liquid Bold's basal medium (BBM;BoLD 1949). Harvested biomass (approx. $500 \mathrm{mg}$ ) was split into twelve parts which were exposed to tritiated water with activity $0,100,500$ and $1000 \mathrm{~Bq}$ (three replicates) for 21 days. After 1 day of exposure subsamples $(100 \mathrm{mg})$ were taken and tested for ROS activity and expression of catalase gene. After 21 days following exposure the algal biomass was tested for morphological changes, expression of catalase gene and ROS production.

Evaluation of morphological variability under a gradient of soft $\boldsymbol{\beta}^{-}$irradiation. Morphological changes of $P$. basilense and $S$. nanum such as cell shape, dimensions, cell cytology or cell division and reproduction were evaluated after 21 days of exposure as follows: 1) samples were photographed using with Zeiss AxioImager (obj. C-Apochromat 40×/N.A. 0,75, HRc camera 13MPx); 2) photographed cultures were analyzed using with Zeiss AxioVision 4.9.1. software; 3) dimensions of one hundred cells (width, length) were measured for all replicates. Descriptive statistics and One Way ANOVA were used for statistical evaluation of taken data (NCSS statistical package, HinTZE 2007).

Quantitative reverse transcriptase polymerase chain reaction (qRT-PCR). Total RNA was isolated from $100 \mathrm{mg}$ of fresh biomass per each sample of green algae after 1 and 21 days of tritium treatment (control, 100, 500, $1000 \mathrm{~Bq}$ ) using the Spectrum Plant Total RNA kit (Sigma-Aldrich, St. Louis, $\mathrm{MO}$ ). The RNA was quantified by spectrophotometric analysis. Prior to amplification all RNA samples were treated with RNase-free DNase (Promega, Madison, WI) to eliminate genomic DNA contamination. The isolated RNA was transcribed to cDNA by Transcriptor High Fidelity cDNA Synthesis Kit (Roche, Basel, Switzerland). Reverse transcription (RT) was carried out in total volume of $20 \mu \mathrm{l}$ containing $1 \mu \mathrm{l}$ anchored-oligo(dT) 18 primers $\left(50 \mu \mathrm{mol}^{-1^{-1}}\right), 9 \mu 1$ total RNA, $1.4 \mu 1$ RNase Free ddH2O, $4 \mu 1$ RT reaction buffer (5times conc.), $0.5 \mu 1$ protector RNase inhibitor (40 U. $\left.\mu 1^{-1}\right), 2$ ul deoxynucleotide mix $\left(10 \mathrm{mmol}^{-1} \mathrm{l}^{-1}\right), 1.1 \mu \mathrm{l}$ reverse transcriptase $\left(20\right.$ U. $\left.\mu l^{-1}\right)$ and $1 \mu 1$ dithiotreitol. The RT reaction was carried out at $45^{\circ} \mathrm{C}$ one hour and enzyme was inactivated by heating to $85^{\circ} \mathrm{C}$ for 5 minutes. The qRT-PCR was done to analyze catalase expression in the green algae using LightCycler ${ }^{\circledR}$ Fast Start DNA MasterPlus SYBR Green I kit (Roche, Basel, Switzerland) in total volume $20 \mu 1$ containing $5 \mu 1$ of complementary DNA (250 ng). The amplification was performed in LightCycler Nano Real - Time PCR System. The appropriate primer sequences are: (forward) 5'- CTC GAA CTA CCG CCA CAT GCG-3' and (reverse) 5'- GCG GTC TGC AGC AGC TTG TC $-3^{\prime}$ for catalase; (forward) 5'-GAA GAC CTT CGC TCG AGG AGG-3' and (reverse) $5^{\prime}-$ CCC ACT CGT TGT CG TAC CA-3' for GAPDH as a housekeeping gene. These primers were synthetized by Generi Biotech (Hradec Kralové, Czech Republic). The PCR reaction mixture contained forward and reverse primers in final concentration 0.5 $\mu$ mol. $1^{-1}(1 \mu \mathrm{l})$, Master Mix 5times conc. $(4 \mu \mathrm{l})$, water PCR grade $(10 \mu \mathrm{l})$ and $5 \mu \mathrm{l}$ cDNA. PCR conditions were as follows: pre-incubation at $95^{\circ} \mathrm{C}$ for $10 \mathrm{~min}$, followed by 40 cycles of denaturation at $95^{\circ} \mathrm{C}$ for $10 \mathrm{~s}$, annealing at $49^{\circ} \mathrm{C}$ for GAPDH, $51{ }^{\circ} \mathrm{C}$ for catalase for $30 \mathrm{~s}$, extension at $72{ }^{\circ} \mathrm{C}$ for $20 \mathrm{~s}$ and finally $5-$ min incubation at $72{ }^{\circ} \mathrm{C}$. The primary data (Cq) were analyzed by LightCycler Nano Software 1.1. Gene expression was normalized per Glyceraldehyde-3-phosphate dehydrogenase as a housekeeping gene. Data were processed by the delta-delta method, compared to the expression levels in control samples. The experiment was repeated three times. Melting curve analysis was carried out to confirm specificity of each product. Melting curve conditions were $60^{\circ} \mathrm{C}$ to 97 ${ }^{\circ} \mathrm{C}$ at $0.1^{\circ} \mathrm{C} . \mathrm{s}^{-1}$. 
Localization of oxygen radicals by confocal microscopy. The free radical sensor 2',7'-dichlorodihydrofluorescein diacetate (DCDHF DA; Molecular Probes, ThermoFisher Scientific, Inc.), was used for in-vivo imaging of RONS generated 1 and 21 days after application of tritium. After hydrolysis of the diacetate groups by cytosolic esterases the non-fluorescent fluorescein derivative is transformed to fluorescent dichlorofluorescein (DCF) upon reaction with peroxynitrite, hydroxyl radical and peroxyl radical. Formation of DCF (maximum $\lambda_{\mathrm{ex}}=495 \mathrm{~nm}, \lambda_{\mathrm{em}}=523 \mathrm{~nm}$ ) was monitored by confocal laser scanning microscopy.

Pseudendoclonium basilense and Stigeoclonium nanum cells from different treatments were incubated either in the absence or presence of $20 \mu \mathrm{M}$ DCDHF DA in darkness for 10 minutes. Immediately after staining, the cells were transferred to fresh water and visualized by confocal laser scanning microscopy (Fluorview 1000 unit attached to IX80 microscope; Olympus Czech Group, Prague, Czech Republic). The excitation of fluorochrome was achieved by a $488 \mathrm{~nm}$ line of an argon laser and signal was detected by a 505-550 nm emission filter. Chlorophyll autofluorescence was visualized by chlorophyll excitation with $543 \mathrm{~nm}$ helium-neon laser, and emission recorded with a $655-755 \mathrm{~nm}$ band pass filter. Cell morphology was visualized by a transmitted light detection module with $405 \mathrm{~nm}$ excitation using a near ultraviolet diode laser and Nomarski DIC filters. The proper intensity of all lasers was set according to unstained samples at the beginning of each experiment. Microscopic analysis was repeated for two sets of algal samples from independent growth and tritium treatment. Integral distribution of signal intensity (0-4096) in 12-bit microphotographs was evaluated by image analysis software FV10-ASW Viewer 4.0 (Olympus).

\section{Results}

Changes in cell dimensions and morphology under gradient of soft $\boldsymbol{\beta}^{-}$irradiation

Pseudendoclonium basiliense showed significant morphological differences along the gradient of soft $\beta^{-}$irradiation, both in cell length and width but not in length/ width ratio (Figs 1-3, Table 1). However, differences in cell dimensions did not exhibit a dose-dependent pattern to the tritium gradient. The longest and widest cells were found in untreated medium and under activity $1000 \mathrm{~Bq}$, whilst cells under 100 and $500 \mathrm{~Bq}$ were the smallest both in length and width. Length/ width ratios did not show any significant variation. In contrast to characteristic shape of natural thallus, cultured algae usually formed spherical to oval cells and pseudoparenchymatous aggregates, with rare lateral branches. Control samples most closely resembled the natural appearance of environmental thalli (Fig. 4). Cells tended to form similar aggregation of spherical or hemispherical cells into irregular colonies with lateral branches. On the other hand, along gradient of $\beta^{-}$irradiation cells became more elliptical and the thallus lost its characteristic arrangement (Figs 5-7). No zoospores were produced under tritium treatments.

Stigeoclonium nanum showed more obvious morphological changes under tritium treatment than Pseudendoclonium basilense (Figs 1-14). Untreated samples of both taxa resembled samples collected from natural populations (e.g., field collected)? Increasing activity of tritiated water stimulated cell elongation of $S$. nanum from $11.99 \pm 8.82$ (activity $0 \mathrm{~Bq}$ ) to 23.01 $\pm 3.85 \mu \mathrm{m}$ (activity $1000 \mathrm{~Bq}$; Fig. 8, Table 1), along with changes in cell structure (especially development of chloroplasts, which are smaller under 1000 $\mathrm{Bq}$ in comparison to $0 \mathrm{~Bq}$ of triatiated medium) and shape of apical cells (from pointed to rounded or almost spherical; see arrows at Figs 11-14). Cell width was not affected oppositely to length/width ratio which showed increasing trend similarly to cell length (Fig 9-10). Asexual reproduction by zoospores was stimulated only at $500 \mathrm{~Bq}$ of soft $\beta^{-}$irradiation whilst production of zoospores at 100 and $1000 \mathrm{~Bq}$ was rarely observed. Filament branching underwent a conspicuous change from regularly branched filaments at $0 \mathrm{~Bq}$ to irregularly branched filaments at 100 and $500 \mathrm{~Bq}$. The highest value of tritiated water activity (1000 Bq) caused stub formation of branches usually consisting of one elongated and rounded cell (Fig. 14). Cells of $P$. basilense remained spherical or elliptical shape under gradient of tritiated medium. Chloroplasts did not show any marked changes and infilled almost the whole cell volume. In contrast to $S$. nanum, we did not observed any zoospores or zoosporangia formation.

\section{Effect of tritium on the catalase expression in the green algae}

We compared the effect of tritium exposure on the expression of catalase in Pseudendoclonium basilense and Stigeoclonium nanum. We did not find any significant changes in catalase expression in case of 1 day exposure. Conversely, the activity of tritium (100, 500, $1000 \mathrm{~Bq}$ ) induced synthesis of catalase RNA. After 21 days of incubation, catalase activity in $P$. basilense was $2.2 \times, 1.4 \times$, and $5.1 \times$ higher than in untritiated medium (see Fig. 15). The highest level (5.1-fold) of catalase RNA was observed under $1000 \mathrm{~Bq}$. No evident changes in catalase expression were found in $S$. nanum after 21 days of incubation.

\section{Imaging of reactive oxygen species}

To elucidate sites of oxidative stress, the fluorescence signal of DCF was visualized within cells of both algal species and complemented by analysis of corresponding integral distribution of DCF signal intensities.

Radicals formed during Pseudendoclonium basilense metabolism were detected in control cells, especially in those dying or undergoing division (Figs 16, 17). Activity of $1000 \mathrm{~Bq}$ caused increase of DCF signal when applied for 1 day. Conversely, the signal was decreased after application of $100 \mathrm{~Bq}$ and 500 $\mathrm{Bq}$ and almost completely abolished in $1000 \mathrm{~Bq}$ cells 

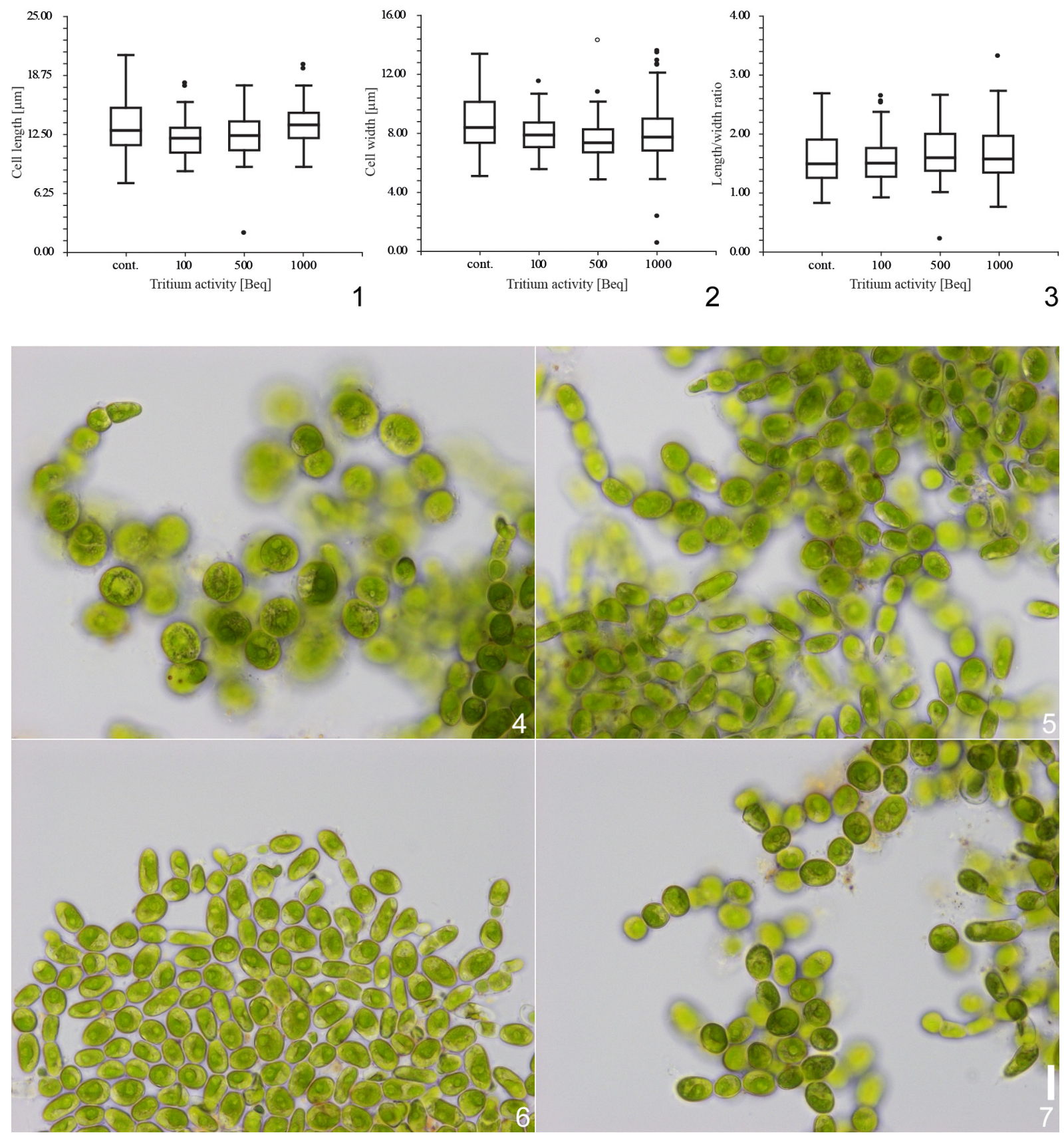

Figs 1-7. Evaluation of morphological variability of Pseudendoclonium basilense under gradient of tritium activity: (1) variability of cell length, (cont.) untritiated medium, $13.27 \pm 2.98 \mu \mathrm{m}$, (100) $100 \mathrm{~Bq}, 12.13 \pm 2.10 \mu \mathrm{m}$, (500) $500 \mathrm{~Bq}, 12.35 \pm 2.35 \mu \mathrm{m}$, (1000) $1000 \mathrm{~Bq}, 13.59 \pm 2.13$ $\mu \mathrm{m}, \mathrm{F}=5.14, \mathrm{p}=0.0018 ;$ (2) variability of cell width, (cont.) untritiated medium, $8.56 \pm 1.75 \mu \mathrm{m},(100) 100 \mathrm{~Bq}, 7.91 \pm 1.28 \mu \mathrm{m},(500) 500 \mathrm{~Bq}$, $7.64 \pm 1.46 \mu \mathrm{m},(1000) 1000 \mathrm{~Bq}, 8.10 \pm 2.50 \mu \mathrm{m}, \mathrm{F}=2.73, \mathrm{p}=0.045$; (3) variability of length/width ratio, (cont.) untritiated medium, $1.61 \pm 0.46$ $\mu \mathrm{m},(100) 100 \mathrm{~Bq}, 1.58 \pm 0.40 \mu \mathrm{m},(500) 500 \mathrm{~Bq}, 1.67 \pm 0.43 \mu \mathrm{m},(1000) 1000 \mathrm{~Bq}, 2.20 \pm 3.11 \mu \mathrm{m}, \mathrm{F}=2.05, \mathrm{p}=0.108$; (4) thallus cultivated at activity $\mathrm{A}=0 \mathrm{~Bq}$; (5) thallus cultivated at activity $\mathrm{A}=100 \mathrm{~Bq}$; (6) thallus cultivated at activity A $=500 \mathrm{~Bq}$; (7) thallus cultivated at activity A $=1000$ Bq. Scale bar $10 \mu \mathrm{m}$.

stressed for 21 days (Figs 18, 19). The combination of Nomarski DIC, DCF fluorescence, and chlorophyll fluorescence channels revealed localization of oxidative stress both in chloroplasts and also in cytoplasm. On the other hand, strains of Stigeoclonium nanum produced only low amounts of RONS which gave very low DCF signal. No significant changes in the DCF fluorescence signal intensity were detected among different treatments (Figs 20-23).

\section{Discussion}

Stress, both abiotic and biotic, represents one the most effective tools of selection and evolutionary pressure. Depending on the extent and intensity, a stress factor can affect organisms on local or global level. Ionizing radiation as a global abiotic factor influences organisms during their entire lifespan. Plant reactions to ionizing radiation include death, growth inhibition, or 

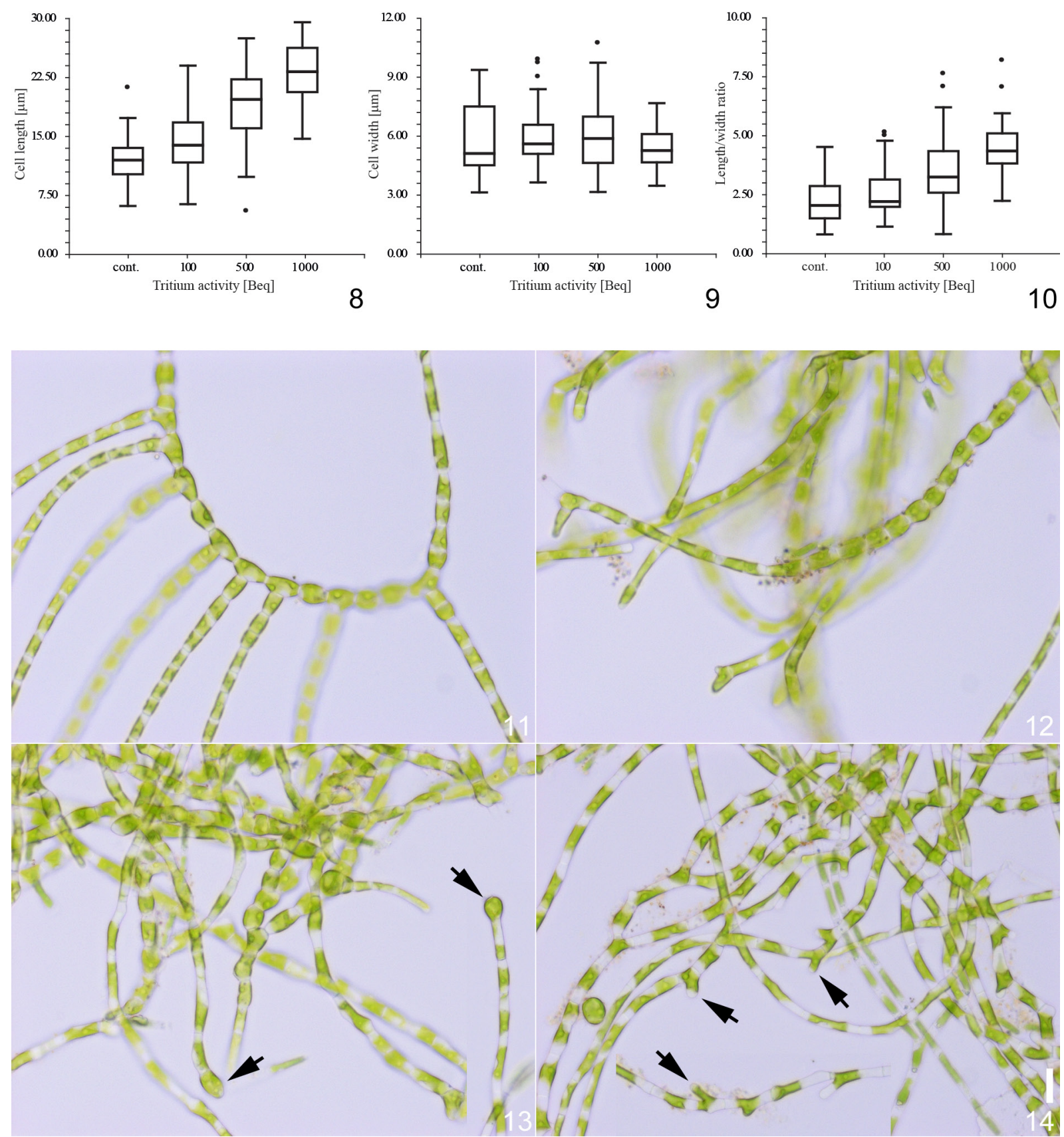

Figs 8-14. Evaluation of morphological variability of Stigeoclonium nanum under gradient of tritium activity: (8) variability of cell length, (cont.) untritiated medium, 11.99 $\pm 2.82 \mu \mathrm{m},(100) 100 \mathrm{~Bq}, 14.77 \pm 3.82 \mu \mathrm{m},(500) 500 \mathrm{~Bq}, 19.11 \pm 4.77 \mu \mathrm{m},(1000) 1000 \mathrm{~Bq}, 23.01 \pm 3.85 \mu \mathrm{m}$, $\mathrm{F}=88.66, \mathrm{p}<<0.001$; (9) variability of cell width, (cont.) untritiated medium, $5.89 \pm 1.74 \mu \mathrm{m}$, (100) $100 \mathrm{~Bq}, 5.93 \pm 1.35 \mu \mathrm{m},(500) 500 \mathrm{~Bq}$, $5.90 \pm 1.64 \mu \mathrm{m},(1000) 1000 \mathrm{~Bq}, 5.35 \pm 0.94 \mu \mathrm{m}, \mathrm{F}=2.01, \mathrm{p}=0.114 ;$ (10) variability of length/width ratio, (cont.) untritiated medium, $2.24 \pm 0.94$ $\mu \mathrm{m},(100) 100 \mathrm{~Bq}, 2.63 \pm 0.99 \mu \mathrm{m},(500) 500 \mathrm{~Bq}, 3.50 \pm 1.37 \mu \mathrm{m},(1000) 1000 \mathrm{~Bq}, 4.44 \pm 1.09 \mu \mathrm{m}, \mathrm{F}=43.26, \mathrm{p}<<0.001$; (11) thallus cultivated at activity $\mathrm{A}=0 \mathrm{~Bq} ;(12)$ thallus cultivated at activity $\mathrm{A}=100 \mathrm{~Bq}$; (13) thallus cultivated at activity $\mathrm{A}=500 \mathrm{~Bq}$, arrows indicate spherical to capitate apical cells; (14) thallus cultivated at activity A $=1000 \mathrm{~Bq}$; arrows indicate stump-like lateral branches. Scale bar $10 \mu \mathrm{m}$.

morphogenetic abnormalities and vary as a function of dose and time (GunCKel et al. 1953; GunCKel \& SPARrow 1954). Low energy soft $\beta$ - irradiation has not been considered as harmful irradiation causing death or significant irreversible changes of organisms. Activities of the tritiated water used in our experiments are similar to surface waters in close proximity to nuclear power plants (NPP) in the Czech Republic $(\sim 10-500$ $\mathrm{Bq} . \mathrm{l}^{-1}$, data from website Monitoring of Radiation
Situation, Czech Office for Nuclear Safety) and in freshwater in rivers downstream of NPP (HANSLík et al. 2009). These levels of radiation have not been believed harmful for organisms living in such environment. Thus, our results evoke a question as to whether these low levels of activity really are safe or whether they can cause stress, which would inevitably lead to adaptation or death. In our study, we found changes in algae exposed to tritiated water on both morphological and 


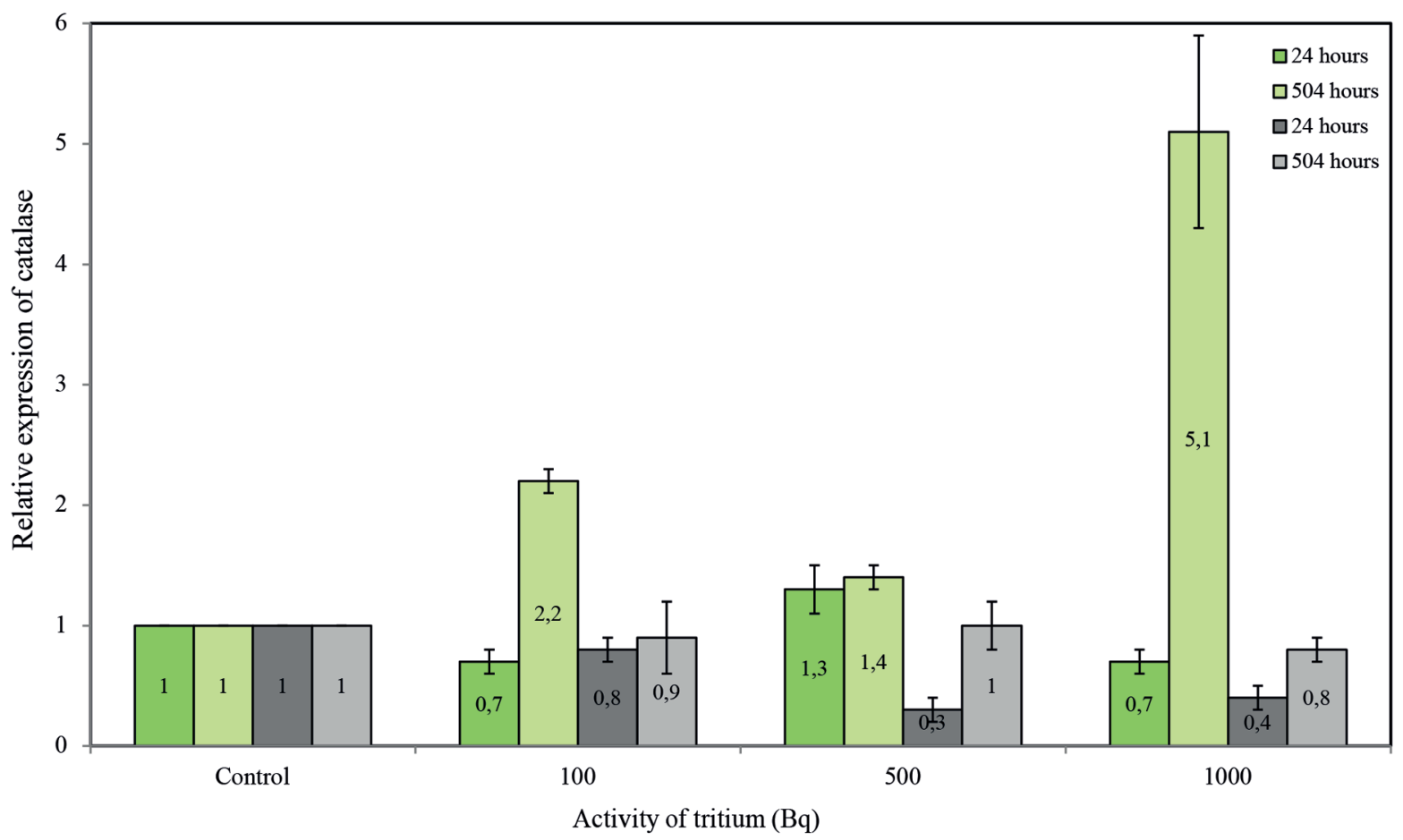

Fig. 15. Catalase gene expression of Pseudendoclonium basilense (green) and Stigeoclonium nanum (grey) under gradient of tritiated water activity.

molecular levels. The most noticeable were changes in the cell shape and cell dimensions. Previous, similar investigations on vascular plants (i.e., apples, bananas) showed structural changes of cells, such as in cell walls and cytoplasm with organelles. Irradiated cell walls usually lose firmness because of pectin degradation (KovÁCs \& Kerestezs 2002). Thus, short stump-like branches and spherical to globose apical cells in algae can be related to irregular growth because of changes of cell wall structure. Similarly, irradiated chloroplasts of vascular plants exhibit changes their ultrastructure, dilatations of intra thylakoid space, and loss of granal stacking (KovÁcs \& Kerestezs 2002). The strain of Stigeoclonium nanum exhibited the most visible changes of chloroplasts especially at $1000 \mathrm{~Bq}$. On the other hand, $P$. basilense did not show any obvious changes in chloroplast shape and arrangement. It seems that morphological answer to ionizing radiation at low level of activity is specific depending on particular species and its adaptability.

Ionizing radiation plays an important role in cell stress, and may be moderated through the network of metabolic pathways. Reactive oxygen species such as $\mathrm{H}_{2} \mathrm{O}_{2}, \mathrm{O}_{2}{ }^{--}$or $\cdot \mathrm{OH}$ play important roles in signaling pathways (e.g. Azzam et al. 2012; TognetTI et al. 2012; KRISHNAMURTHY \& RathinASABAPATHi 2013). At low levels, ROS can act as secondary messengers that transfer stress signals and facilitate responses to various environmental conditions or stress. The concentration of ROS depends on both production and scavenging efficacy, influenced by internal and external stimuli.

ROS production is rapid and localized, initiated immediately after stimulus action. The degree of reaction depends on individual factors, such as intensity and timing. For example, Arabidopsis thaliana can produce ROS in waves within as little as 10 minutes following wounding (MitTLER et al. 2011). RÉTY et al. (2012) observed peak of ROS production between 14 and 15 min after tritiated water exposure in the alga Chlamydomonas reinhardtii, followed by a rapid decrease and leveling off within 45 minutes. Chlamydomonas likely reduced ROS production due to activity of protective enzymatic system. Neither cell growth or size of $C$. reiherdtii was affected by the addition of tritiated water. Herein, both tested strains $P$. basilense and $S$. nanum showed stress responses within 1 day after exposure. However, only P. basilense was stimulated by the addition of tritiated water for ROS production. On the other hand, S. nanum was unaffected by tritiated water. In both of our strains, ROS concentrations later equilibrated to a constant level within 21 days after inoculation of both strains, similar to that seen in C. reinhardtii (RÉTY et al. 2012). Changes of ROS concentrations indicate a capability to respond to environmental stress. In our study, $P$. basilense exhibited a low but permanent response to tritiated water via upregulation of catalase gene expression. This adaptation led to decreasing of ROS concentration in cells making new balanced homeostasis as found in Chlamydomonas reinhardtii. On the other hand, S. nanum exhibited changes in cell morphology (e.g., cell 



Figs 16-19. ROS production of Pseudendoclonium basilense in untritiated $(0 \mathrm{~Bq})$ and tritiated medium $(1000 \mathrm{Bg}) 1$ and 21 days after treatment, (DIC) Nomarski differential contrast, (chlorophyll) autofluorescence of chlorophyll-a in red, (DCF) green fluorescence of dichlorofluorescein, arrows show intensive positive signal, (DFC intensity) integral distribution of DCF signal intensity: (16) 1 day, A = 0 Bq; (17) 1 day, A = 1000 Bq; (18) 21 days, $A=0$ Bq; (19) 21 days, $A=1000$ Bq. Scale bar $10 \mu \mathrm{m}$

elongation and the presence of spherical apical cells), possibly due to the role of auxins. Direct water radiolysis via ionizing radiation is known to induce the production of both ROS species and $\mathrm{H}_{2} \mathrm{O}_{2}$ (BENSASSON et al. 1993). ROS are known to be involved in both cell wall loosening and reinforcement. Plant peroxidases utilize $\mathrm{ROS}$ and $\mathrm{H}_{2} \mathrm{O}_{2}$ to produce phenolic radicals in cell walls and consequently create cross-links via these radicals. Cross-linking of the cell wall components leads to cell wall tightening and could result in a growth restriction (KäRKÖNEN \& KUCHITSU 2015). We speculate that similar process might contribute to $\mathrm{H}_{2} \mathrm{O}_{2}$ removal from $S$. nanum cells. If expression of the catalase gene was not upregulated then the altered thickness of the cell wall could lead to changes in cell shape.
Moreover, ROS, together with $\mathrm{Ca}^{+}$and $\mathrm{pH}$, were reported to sustain polar growth in plant cells over the time (Mangano et al. 2016) and thus affect development of Stigeoclonium nanum fibers through changes in cell wall dynamics.

Studies (PASTERnAK et al. 2002, 2005) have demonstrated that mild oxidative stress could mimic the effect of auxin on plant development. For example, inhibition of catalase activity, as well as direct $\mathrm{H}_{2} \mathrm{O}_{2}$ treatment, of Lycium barbarum calli stimulated embryogenesis (CUI et al. 1999) in a manner similar to auxin application. Auxins also inhibit shoot branching and promote lateral root formation (PASTERNAK et al. 2002) and polar auxin transport is thought to play a key role in such processes. Auxin transport has recently 



Figs 20-23. ROS production of Stigeoclonium nanum in untritiated (0 Bq) and tritiated medium (1000 Bg) 1 and 21 days after treatment, (DIC) Nomarski differential contrast, (chlorophyll) red autofluorescence of chlorophyll-a, (DCF) green fluorescence of dichlorofluorescein, arrows show positive signal, (DFC intensity) integral distribution of DCF signal intensity: (20) 1 day, A = 0 Bq; (21) 1 day, A = 1000 Bq; (22) 21 days, $\mathrm{A}=0 \mathrm{~Bq}$; (23) 21 days, $\mathrm{A}=1000 \mathrm{~Bq}$. Scale bar $10 \mu \mathrm{m}$.

been described in the green alga Chara (ZHANG \& VAN Duisn 2014). We hypothesize that oxidative stress induced by tritiated water treatment also mimics auxins which could disturb polar auxin transport in $S$. nanum leading to changes in branching.

The level of tritiated water in our study was low without perceivable harmful or damaging effects. The two different algal species reacted differently to low dose exposure to tritiated water. They exhibited different morphological responses and gene expression as adaptive stress response. Thus, soft $\beta$ radiation should be considered as low energy radiation capable of causing cell stress which influences cell morphology, metabolism, and gene expression.
ACKNOWLedGement

This study was supported by Palacký University in Olomouc through grant no. IGA PrF-2017-001. The authors are thankful to prof. Dale A. Casamatta (University of North Florida) for language revision of the manuscript.

\section{REFERENCES}

AzZAM, E.I.; JAY-Gerin, J.-P. \& PAIN, D. (2012): Ionizing radiation-induced oxidative stress and prolonged cell injury. - Cancer Letters 327: 48-60.

Baglan, N.; Kim, S. B.; Cossonnet, C.; Croudace, I. W.; FourNier, M.; Galeriu, D.; Wareick, P. E.; Momoshima, N. \& ANSOBoRlo, E. (2013): Organically bound tritium (OBT) behaviour and analysis: outcomes of the seminar held in Balaruc-les-Bains in May 2012. - Radioprotection 48: 
$127-144$.

Bensasson, R.V.; Land, E.J. \& Tuscott, T.G. (1993): Light and ionizing radiation: generation of excited states and radicals. - In: Bensasson, R.V.; Truscott, T.G. \& LAND, E.J. (eds): Excited States and Free radicals in Biology and Medicine: Contribution from Flash Photolysis and Pulse Radiolysis. - pp. 249-289, Oxford University Press, New York.

Bonotto, S.; Gerber, G. B.; Arapis, G. \& Kirchmann, R. (1982): Modelization of tritium transfer into the organic compartments of algae. - Annales de I'Association belge de radioprotection $7: 183-291$

Blaylock, B.G.; Hoffman, F.O. \& Frank, M.L. (1986): Tritium in the aquatic environment. - Radiation Protection Dosimetry 16: 65-71.

Belot, Y. (1986): Tritium in plants: a review. - Radiation protection dosimetry 16: $101-105$.

Bold, H. C. (1949): The morphology of Chlamydomonas chlamydogama sp. nov. - Bulletin of the Torrey Botanical Club 76: 101-108.

Calmon, P. \& Garnier-Laplace, J. (2010): Tritium and the environment. -26 pp., Institut de radioprotection et de sureté nucléaire. Paris.

CuI, K.R.; XING, G.S.; Liu, X.M.; XING, G.M. \& Wang, Y.F. (1999): Effect of hydrogen peroxide on somatic embryogenesis of Lycium barbarum L. - Plant Sci. (146): 9-16.

Dat, J.; Vandenabeele, E.; Vránová, E.; Van Montagu, M.; InZÉ, D. \& VAN BReusegem, F. (2000): Dual action of the active oxygen species during plant stress responses. - CMLS, Cell. Mol. Life Sci. 57: 779-795.

Fiévet, B.; Pommier, J.; Voiseux, C.; Du Bois, P.B.; Laguionie, P.; Cossonnet, C. \& Solier, L. (2013): Transfer of tritium released into marine environment by French nuclear facilities bordering the English Channel. - Environ. Sci. Technol. 47: 6696-6703.

Gunckel, J. E.; Morrow, I. B.; Sparrow, A. H. \& Christensen, E. (1953): Variations in the floral morphology of normal and irradiated plants of Tradescantia paludosa. - Bulletin of the Torrey Botanical Club 80: $445-456$.

Gunckel, J. E. \& Sparrow, A. H. (1954): Aberrant growth in plants induced by ionizing radiation. - Brookhaven symposia in biology 6: $252-279$.

Hanslík, E.; Ivanová, D.; Juranová, E.; ŠimoneK, P. \& JEDINÁKOVÁ-KŘižzvÁ, V. (2009): Monitoring and assessment of radionuclide discharges from Temelín nuclear power plant into Vltava river (Czech Republic). - J. Envir. Radioact. 100: 131-138.

HARrison, F. L. (1971): Biological implications of nuclear debris in aquatic ecosystems. - Nuclear technology 11: $444-$ 458.

Hintze, J. (2007): NCSS 2007. - NCSS, LLC. Kaysville, Utah, USA. www.ncss.com.

JEAN-BAPtiste, P. \& FourRé, E. (2013): The distribution of tritium between water and suspended matter in a laboratory experiment exposing sediment to tritiated water. - Journal of environmental radioactivity 116: $193-196$.

KÄrkönen, A. \& Kuchitsu, K. (2015): Reactive oxygen species in cell wall metabolism and development in plants. Phytochemistry 112: 22-32.

Kim, S. B.; Bredlaw, M. \& Korolevych, V. Y. (2012): HTO and OBT activity concentrations in soil at the historical atmospheric HT release site (Chalk river laboratorie). Journal of environmental radioactivity 103: $34-40$.

Kirchmann, R.; Bonotto, S.; Soman, S. D.; Krishnamoorthy, T. M.; Iyengar, T. S. \& Moghissi, A. A. (1979): Transfer and incorporation of tritium in aquatic organisms. - In: Behaviour of tritium in the environment. - pp. 187-203, IAEA-SM, Vienna.
KovÁcs, E. \& Keresztes, Á. (2002): Effect of gamma and UV$-\mathrm{B} / \mathrm{C}$ radiation on plant cells. - Micron 33: $199-210$.

Krishnamurthy, A. \& Rathinasabapathi, B. (2013): Oxidative stress tolerance in plants. Novel interplay between auxin and reactive oxygen species signaling. - Plant Signaling \& Behavior 8: http://dx.doi.org/10.4161/psb.25761.

Mangano, S.; JuÁrez, S.P.D. \& Estevez, J.M. (2016): ROS regulation of polar growth in plant cells. - Plant Physiol. 171: 1593-1605.

McClung, C. R. (1997): Regulation of catalases in Arabidopsis. - Free Radical Biology and Medicine 23: 489-496.

McCubbin, D.; Leonard, K. S.; Bailey, T. A.; Williams, J. \& Tossell, P. (2001): Incorporation of organic tritium $(3 \mathrm{H})$ by marine organisms and sediment in the severn estuary/Bristol channel (UK). - Marine pollution bulletin 42: $852-863$.

Mittler, R.; Vanderauwera, S.; Suzuki, N.; Miller, G.; Tognetti, V.B.; Vandepoele, K.; Gollery, M.; Shulaev, V. \& VAN Breusegem, F. (2011): ROS signaling: the new wave? - Trends in Plant Science 16: 300-309.

Pasternak, T.; Potters, G.; Caubergs, R. \& Jansen, M.A.K. (2005): Complementary interactions between oxidative stress and auxins control plant growth responses at plant, organ, and cellular level. - J. Exp. Bot. 56: 1991-2001.

Pasternak, T.; Prinsen, E.; Ayaydin, F.; Miskolczi, P.; Potters, G.; Asard, H.; van Onckelen, H. \& Fehér, A. (2002): The role of auxin, $\mathrm{pH}$ and stress in the activation of embryogenic cell division in leaf protoplast-derived cells of alfalfa. - Plant Physiol. 129: 1807-1819.

Potters, G.; Pasternak, T.P.; Guisez, Y.; Palme, K.J. \& Jansen, A.K. (2007): Stress-induced morphogenic responses: growing out of trouble? - Trends in Plant Science 12: 1360-1385.

Réty, C.; Gilbin, R. \& Gomez, E. (2012): Induction of reactive oxygen species and algal growth inhibition by tritiated water with or without copper. - Environ. Toxicol. 27: $155-165$.

Tognetti, V.B.; Mühlenbock, P. \& van Breusegem, F. (2012): Stress homeostasis - the redox and auxin perspective. Plant, Cell and Environment 35: 321-333.

Willekens, H.; Chamnongrol, S.; Davey, M.; Schraudner, M.; Langebartels, C.; van Montagu, M.; Inzé, D. \& van CAmp, W. (1997): Catalase is a sink for $\mathrm{H}_{2} \mathrm{O}_{2}$ and is indispensable for stress defence in $\mathrm{C}_{3}$ plants. - EMBO J. 16: 4806-4816.

Zhang, S. \& van DuIJn, B. (2014): Cellular auxin transport in algae. - Plants 3: 58-69.

(C) Czech Phycological Society (2017)

Received February 2, 2016

Accepted March 21, 2017 